\title{
Dimensions of Language Education Policy in Asia
}

\author{
Anthony J. Liddicoat and Andy Kirkpatrick
}

\section{Introduction}

Language education policy in Asia has shown significant and rapid development since the middle of the twentieth century, when many countries in the region gained independence. While there have been many studies of language education policy in the various countries of Asia, there has been less research that has sought to examine the region as a whole. This paper aims to develop a review of language in education planning in the Asian region based on the work of the thirty-five authors of the individual country chapters in the recently published (2019) Routledge International Handbook of Language Education Policy in Asia of which we were the co-editors. The information for each country comes from a range of sources including document surveys, policy analysis and field work. We use this information to develop a synthesis for each of four regions into which Asia is traditionally divided: East Asia, Southeast Asia, Central Asia and South Asia, and then draw out some common themes that can been seen in the region as a whole.

The article starts with an overview of language education policy across the four regions. There then follows a case study from each of the four regions, which have been chosen to highlight aspects of language in education policy in the wider region and also show something of the local distinctiveness of the country. The case studies focus on Hong Kong and China for East Asia, the Philippines for Southeast Asia, Uzbekistan for Central Asia and Bangladesh for South Asia. We then discuss the common themes in language education policy we have been able to identify and conclude by suggesting the implications of these common themes for language education as a whole. In short, we argue that, with some exceptions which we describe below, current trends show that indigenous languages other than the respective national language are being neglected as languages of education and that English is being promoted as the second language of education, second in importance only to the national language.

\section{East Asia.}

Almost all the countries and polities of East Asia - North Korea, South Korea, Japan, Mongolia, China, including Hong Kong and Macau, and Taiwan - promote their respective national languages and English as the major languages of education. China proscribes the teaching of Chinese languages other than the national language but allows the teaching of national minority languages. Hong Kong is atypical of the region, having a policy of multilingual education through which citizens are expected to become biliterate in Chinese and English and trilingual in Cantonese, Mandarin and English. Cantonese is a medium of instruction through most primary schools (Wang and Kirkpatrick 2019). The language education policies of China, including Hong Kong, will be treated in more detail in the country case study below. Cantonese is also taught as a medium of instruction in Macau where the goal of the language policy is for people to be able to function in both Cantonese and Mandarin and to be able to write modern standard Chinese. Macau is therefore also atypical in that it promotes both Cantonese and Mandarin and, at the same time, forbids the use of English as medium of instruction (EMI) in the 18 government schools, where it is taught as a subject. Macau's colonial history is reflected in the fact that Portuguese also acts as a medium of instruction, but only in one pre-primary, one primary and one secondary school. The total number of speakers of Portuguese in Macau is very small, comprising some 8000 out of a population of 650,000 . While EMI is forbidden 
in the government schools, many of the subsidised and private schools do use EMI. Macau's only fully comprehensive university, the University of Macau is EMI (Moody 2019).

Taiwan promotes multilingual education, but the extent of this depends on which political party is in power at the time. When the KMT, the party in favour of closer ties with China, is in power, education policy stresses Mandarin and English as the languages of education. When the independence-minded DPP is in power, other Chinese languages such as Min Nan Hua (the language spoken by the majority of Taiwanese as a first language) and some aboriginal languages are promoted. As the DPP is in power at the time of writing the language policy comprises two streams, namely the Local-Language-in-Education (LLE) policy and the English Education (EE) policy. The English Education policy mandates the teaching of English as a subject throughout school, but this only ratifies what had been usual practice for decades. The LLE policy involves the teaching of Taiwanese local languages, culture and history in primary school. Yet, despite the DPP being in power and the promotion of local languages, Mandarin remains the most popular medium of instruction (MoI) in schools (Wu \& Lau 2019).

In Mongolia, Mongolian is the dominant language but comprises a number of dialects. Khalkha is the dominant dialect and is the one spoken around the capital Ulaanbaatar and spoken by $82 \%$ of the population. Other dialect groups include the Oirat ethnic group who live in the far West of Mongolia where there are also Kazakhs who speak a Turkish based language. Russian and English have traditionally been the two dominant second languages. After 1990, however, when Mongolia moved from being a Russian satellite to an independent country with a market economy, English quickly transplanted Russian as the major second language (Dovchin 2017). Unusually for the region, which favours an early start in English, following the 2015 Mongolian Language Law, foreign language instruction cannot start before grade 5. English is taught from Grade 5 as the first foreign language through to the end of secondary school. The 2015 Language Law has also re-afffirmed the use of the Cyrillic Mongolian script for educational and official purposes, and determined the use of Mongol Bichig, the Mongolian writing system,for all official and legal purposes (Marzluf \&Saruul-Erdene 2019).

South Korea and Japan both exemplify the typical model of the national language and English as the major languages of education. High school students in South Korea spend the same amount of time on English as they do on Korean which is 5 times longer than they spend on Japanese, the most popular foreign language after English. As Jeon notes 'Learning English is a lifelong concern for most Koreans' (Jeon 2019: 117).

In Japan, because of the pressure to improve English speaking ability brought about by accelerating globalization, the overall English language class hours in junior high schools (420) now surpass those of the study of the national language (385) for the first time in the history of Japan's educational policy (Honna \& Saruhashi 2019). Both South Korea and Japan are relatively heterogeneous linguistically compared with many other parts of Asia and indigenous languages do not feature in mainstream school curricula. In Japan, teaching guidelines issued in 2011 encourage the teaching of the languages of Okinawa and in Hokkaido, there is some teaching of Ainu language and culture, but with what effect, it remains to be seen (Honna \& Saruhashi 2019).

North Korea is Asia's only completely monolingual country. Korean is the national language. Two themes that have been strongly pursued in North Korean's education are (i) idolisation of the Kim leaders, based on Kim Il Sung's Juche ideology; and (ii) science and technology education, more recently computer technology in particular. English, the language of the 'arch enemy', has long since taken over from Russian as the first foreign language learned in 
school. Russian was actually removed from the curriculum altogether in 1995. Chinese is now the second most popular foreign language. In mainstream government schools English is taught to serve the revolution, as explicitly stated in this passage from an English language textbook (Song 2019: 132):

Teacher: Well, Kim In Su, what do you learn English for?

Student: For our revolution

Teacher: That's right. It's true that we learn English for our revolution

English is also taught to serve the second goal of Korean education, namely for access to science and technology, but the students studying this 'practical' type of English rather than 'ideological' English are carefully chosen. North Korea does not want the majority of it is citizens to have access to practical English. Song (2019) concludes that North Korea will retain ideology-laden English language education as long as it can and will confine practical English language education to special foreign language schools.

\section{Southeast Asia}

Southeast Asia is here taken to mean the ten countries that make up the Association of Southeast Asian Nations (ASEAN). These are, in order of their joining the group, Indonesia, Malaysia, The Philippines, Thailand and Singapore (1967), Brunei (1994), Vietnam (1995), Laos and Myanmar (1997) and Cambodia (1999). While these ten countries may form one regional grouping of nations, they are all very different linguistically, culturally and historically. Brunei, Malaysia, Myanmar, the Philippines and Singapore were all once colonies of English-speaking empires. Indonesia was a colony of the Netherlands and Cambodia, Laos and Vietnam part of French Indo-China. Thailand is the only one of the ten that was not a colony. On achieving independence these nations sought to establish national unity and the adoption of a national language was seen as crucial to this enterprise. A national language is also seen as crucial to Thai nationhood and to a sense of 'Thainess' (Draper 2019). This explains the promotion of the respective national language in the educational systems of each of these countries. At the same time, however, these countries are linguistically richly diverse. For example, more than 700 languages are spoken Indonesia, more than 150 in the Philippines and about 130 in Myanmar. But as Bradley (2019) showed in his review of the language policies of the seven Mainland Southeast Asian nations, none has a systematic language education policy encompassing the teaching of local languages other than the national language. The teaching of indigenous languages is largely left to religious institutions, non-governmental agencies and pilot projects. The situation is somewhat different in Indonesia and the Philippines. Indonesia has mandated the study of a local language at junior secondary level but with limited uptake. Languages with a large number of speakers such as Sundanese and Javanese have benefited by the development of teaching materials and become part of the curriculum. Some 'smaller' languages are now also being taught. For example, Buginese, a language of 5 million speakers, is taught in some schools. Makassarese is taught as a medium of instruction in primary schools in Makassar (Kohler 2019). Other local languages occupy the 'local content' curriculum subject and may be taught for one period a week. Generally speaking, however, few of the indigenous languages of Indonesia are taught in a systematic way. In the Philippines, nineteen languages have been designated as media of instruction in primary schools, and this will be discussed further below, as the Philippines is the country case study. In each country, however, although they may have viewed English in quite different ways and implemented different language policies over the years, all now promote English as the second language of education. Table 1 shows the medium of instruction and when English is introduced to each of the ten countries of ASEAN 
Table 1 The National Language and English in Education in ASEAN (adapted from Kirkpatrick \& Liddicoat 2017)

\begin{tabular}{lll}
\hline Country & Medium of Instruction & First Foreign Language (Year of Introduction) \\
\hline Brunei* & Malay and English & English (primary 1 as MoI) \\
Burma & Burmese & English (primary 1) \\
Cambodia** & Khmer & English (primary 4) (French also offered) \\
Indonesia** & Bahasa Indonesia & English (secondary 1) \\
Laos & Lao & English (primary 3) \\
Malaysia & Malay and Vernacular & English (from primary 1) \\
Philippines & Local languages & English (from primary 1 as MoI) \\
Singapore & English & Malay/Mandarin/Tamil (primary 1) \\
Thailand & Thai & English (primary 1) \\
Vietnam** & Vietnamese & English (primary 3 in selected schools) \\
\hline
\end{tabular}

* The Arabic script, jawi, is introduced from primary 3

** Some bilingual education for minority groups in early primary

A number of points can be noted from Table 1. First, Indonesia is the only country that does not make English a mandatory subject in primary school. It is, however, mandatory at secondary school and in higher education. Second, the Philippines is the only country which uses a range of local languages as media of instruction in primary schools. Third, irrespective of a country's colonial past, in particular whether or not it was a colony of an English-speaking empire, English is the second language of education across all. One reason for this is the perception that English is an essential prerequisite for participating in modernisation and globalisation. In the case of ASEAN, a further motivation for English has been the official adoption of English as the sole working language of ASEAN, as documented in the ASEAN Charter of 2009. The importance of English for ASEAN was emphasised in 2013 by then then Secretary General of ASEAN, Le Luong Minh:

\begin{abstract}
With the diversity in ASEAN reflected in our diverse histories, races, cultures and belief systems, English is an important and indispensable tool to bring our Community closer together. [...] Used as the working language of ASEAN, English enables us to interact with other ASEAN colleagues in our formal meetings as well as day-today communications. [...] In order to prepare our students and professionals in response to all these ASEAN integration efforts, among other measures, it is imperative that we provide them with opportunities to improve their mastery of the English language, the language of our competitive global job market, the lingua franca of ASEAN. (ASEAN 2013
\end{abstract}

In summary, the desire to promote a national language as a symbol of unity and nationhood coupled with the perceived need for English, both for international and regional communication explains each country's promotion of their respective national language and English as primary languages of education.

\title{
Central Asia
}

The Central Asian republics of Kazakhstan, Kyrgyzstan, Tajikistan, Turkmenistan and Uzbekistan all achieved independence from the Soviet Union in the early 1990s and this marked the end of a relatively long period of colonisation by Russia. The experiences of the republics before independence moved between periods of Russification under the Tsarist empire and in the later Soviet Union and a period of ethnic particularisation during the early Soviet period. Following the Revolution of 1917, the Central Asian republics were formed 
around particular titular ethnic groups (Kazakh, Kyrgyz, Tajik, Turkmen and Uzbek) and were encouraged to develop an ethnicity-based identity related to their titular nationality. However, the division of local populations among the republics did not create mono-ethnic states but rather the various ethnic groups in the region were distributed between states and all states have sizable minorities from other ethnic groups, including immigrants from elsewhere in the Soviet Union

As part of their formation as ethnically based states, ethnic languages were given a role as official languages and languages of education alongside Russian. The local languages had not been used for such functions under the empire and literacy levels were relatively low and the languages had not been much used for writing (Liddicoat, 2019). This meant that much early language policy work focused on the development of literacy in local languages and the development of writing systems for the languages. The development of written forms underwent a number of changes during the Soviet period beginning with proposals to develop writing in Arabic script, followed by a phase of development of Latin scripts and finally the entrenchment of the Cyrillic script. These changes were mainly driven by political considerations; Arabic being associated with Islamic religious identity and with historical literate practice, Latin script linking to pan-Turkic identity, especially after the adoption of the Latin script by the Turkish republic in the 1920s and Cyrillic being associated with a move to establish a common Soviet identity and to create linguistic barriers between the republics and ethnic and linguistic groups outside the Soviet Union (Liddicoat, 2019; Regan, 2019). The frequent changes of script had negative consequences for literacy development as literate people were required to relearn literacy skills with each change.

After independence in 1991, these issues of scripts were revisited in the republics with most republics proposing script reform, although these reforms have not yet been fully implemented (Landau, 2010). Most countries have proposed moving to Latin scripts. In some cases (Uzbekistan and Tajikistan), Arabic script was considered but has not been adopted anywhere; Uzbekistan opted for Latin script in 1993, although children are also taught Arabic script, and Tajikistan continues to use Cyrillic (Liddicoat, 2019). The script reforms have not been fully implemented and in most places both Cyrillic and Latin scripts are used alongside each other. The progress towards Latin has been most rapid in Turkmenistan. Kazakhstan has maintained the use of Cyrillic, although a shift to Latin script has been proposed but its implementation has not been a priority (Regan, 2019).

During the Soviet period, the titular languages of the republics had been given co-official status alongside Russian, although for most of the period held an inferior status. In the transition from the Soviet Union to independence, all republics adopted policies that declared the titular language to be the official language, with Russian given secondary status, usually as a interethnic lingua franca (Liddicoat, 2019; Regan, 2019). After independence, this situation has been largely retained, although Kazakhstan is officially bilingual with both languages having the same status and Turkmenistan and Uzbekistan have adopted monolingual policies that has no role for Russian. In all republics however Russian has continued to be used and plays an important role on the sociolinguistic profile of the countries.

In education policy, the titular language became the normal MoI, although there is variation with Russian and some ethnic languages being included as MoIs in most republics. In reality, there was considerable shift to Russian in the republics during the Soviet period and few members of other ethnic groups speak the titular languages and knowledge of the language may even be limited for some members of the titular ethnic group. There has thus been a 
concern in language education policy to strengthen the position of the titular languages and to ensure its uptake by other ethnic groups, however, with limited success (Liddicoat, 2019).

Much language education policy has sought to address some of the complexities of the multiethnic make-up of the republics. It is only in Turkestan that the titular language is the sole MoI in government schools and other languages are explicitly excluded. In Kazakhstan, both Kazakh and Russian MoI schools exist and all students must study the other language (Regan, 2019). Uzbekistan gives a right to use any ethnic language in education but in reality only Kazakh, Kyrgyz, Russian, Tajik and Turkmen have been approved as MoIs, with Karakalpak being used in the semi-autonomous Karakalpakstan republic. Tajikistan also allows ethnic languages to be used in schooling but guarantees only the use of Tajik, Russian and Uzbek, with Kyrgyz and Turkmen permitted in areas where large groups of speakers are found Kyrgyzstan recognises Kyrgyz, Russian and bilingual schools and permits teaching in Tajik and Uzbek, although there a few such schools (Liddicoat, 2019). In all school systems the titular language is a required subject regardless of the MoI and Russian is also required from primary school level. Turkmenistan is the exception and the study of Russian has been variously promoted and curtailed in frequent and often contradictory changes of policy.

English is also highly present in the Central Asian republics and is a required subject in all countries usually beginning in early primary school. This means that most systems have a trilingual policy of the titular language, Russian and English and usually give preference to Russian over English (Liddicoat, 2019; Regan, 2019), although this position is now being challenged by English. However Russian continues to be a key language for regional mobility and cross-border employment and this means that it maintains a local utility that English has not yet rivalled, even though English is seen as a key language for modernisation and international communication.

\section{South Asia}

South Asia (understood here as Afghanistan, Bangladesh, Bhutan, India, Maldives, Nepal, Pakistan, and Sri Lanka) is a highly multilingual region and most of the countries of the region include large numbers of different linguistic communities within their borders. There are, however, exceptions with Maldives being relatively linguistically homogenous, although there are significantly differing varieties of the local language Dhivehi (Gnanadesikan, 2017 ), and Sri Lanka having two main linguistic communities, Sinhala and Tamil, although again with internal diversity (Chandralal, 2010, Kalainathan, 2000). The complex local language situations of these countries have been overlain by the presence of English as the language of the colonising power in most of the countries. Even those countries that were not colonised by the UK (Afghanistan, Bhutan, Nepal) were subject to considerable UK influence. The nations of South Asia thus have had a long history of association with the English language.

As the colonised nations gained independence, there was a strong desire to establish a national identity and the adoption of local languages as official languages played a significant role in this. In many countries, this was achieved by designating a single language as the language of the country (e.g. Urdu in Pakistan, Sinhala in Sri Lanka, Dhivehi in Maldives). In those countries that were not colonised, nation-building in the twentieth century also favoured the adoption of a single official local language (Dzongka in Bhutan, Nepali in Nepal). In language policy terms, there has thus been little recognition or inclusion of complex multilingual realities in language policy decision-making. India provides a notable exception because, although Hindi was designated as the national official language, constitutional recognition has been given to other languages as regional official languages. However even in India many languages 
have no official status (Mohanty, 2019). The selection of a single national official language was not uncontested in many countries often by excluded language groups, especially those with significant numbers of speakers. In Bangladesh, at the time it was East Pakistan, the selection of Urdu was especially contested and when Pakistan divided, Bangla, as the dominant language of the new country, was chosen as the official language.

Although policies tended to adopt local languages as official, English continued to play a role in official communication after independence. This role was sometimes recognised in language statutes by giving English an official status, as in India and Pakistan, where English was declared official largely to enable a transition between the colonial practices of English language administration to local vernaculars and was intended to be a temporary arrangement, or simply continued to be used as a de facto working language. In some cases, the continued use of English has been maintained by local conflicts between language groups as in India where the Hindi-speaking groups have largely sought to downgrade the role of English while non-Hindi-speaking groups have sought to augment its role as a way of contesting the status of Hindi as the national official language (Mohanty, 2019).

Language education policy in the area is complex. In many of the countries, although a local language has been selected as the sole official language, it is not always recognised as the main language of schooling in education policies. Thus in Bhutan, Dzongka is used as the normal MoI only in early primary school ceding place to English over the course of schooling (Dukpa, 2019) and in Maldives Dhivehi takes a secondary place in education to English (Mohamed, 2019). In India, reflecting the multilingual language policy, education policy has largely been based around a three-language formula, based on the students' mother tongue or a regional language, Hindi or another Indian language and English. In reality, however, this policy is not always realised. Mother tongues that are not the dominant language of their regions are rarely used for education, other Indian languages are rarely studied in Hindi-speaking areas, and English tends to have a predominant role in higher levels of schooling (Mohanty, 2019). In Sri Lanka and Pakistan where there are two official languages, education policy requires that students in schools that use one language as a medium of instruction are required to study the other language as a subject (Liyanage, 2019; Spooner \& Nawad, 2019). These policies are largely responses to internal conflicts in the countries, but there is little evidence that they are being implemented effectively.

In all countries of the region, English has a role in the school curriculum varying from study as a subject to use as an MoI and there is evidence across the region that the language is becoming increasingly important. In many countries, the study of English has been pushed earlier and earlier into school and in most countries begins at around Grade 1, at least in official policy, although it is not always possible for schools to ensure teaching English from this level, especially in rural areas. Policies have also begun to offer increased space of English as the MoI. It would appear that the opening of opportunities for using English in government schools has been driven to some extent by the practices of private schools, in which EMI has become the established norm (Hamid \& Rahman, 2019; Phyak \& Ojha, 2019). In those countries where EMI is not normal practice in government funded education, private schools have increasingly used EMI as form of distinction within the education system. Education for elites is becoming increasingly English language focused in all countries of the region and there is an emerging class divide based on access to English language education, which grants possibilities for better employment, further study and social mobility. There is also an emerging rural-urban divide as there is better access to English-language programs in cities than in rural areas. 
Local languages other than those with official status tend to be marginalised in education and few languages are present in schools. In Bhutan, for example, education policy states that local languages are important, but that the place for learning them is the home and the school is reserved only for Dzongka and English (Dukpa, 2019). In India and Pakistan, there are some local languages used in education, but they represent a small proportion of the languages spoken in the country are often under resourced and have other problems of implementation (Mohanty, 2019; Tariq Rahman, 2019). In Nepal, the recent establishment of a federal system has delegated language and education decision-making to provinces and this appears to be opening spaces for local languages to be used for educational purposes, at least in some areas, although this development is slow and educational change is more characterised by increasing English language education than by the inclusion of local languages (Phyak \& Ojha, 2019). In many countries of the region, there have been experimental programs in mother tongue-based multilingual education (MTB-MLE), but these have not been well-integrated into the education system and tend to be limited, transitory and dependent on external resources (Mohanty, 2019; Tariq Rahman, 2019).

In educational policy, English seems to be becoming increasingly dominant and taking on a larger share of the curriculum in all countries. In most places, English is competing with the local official language for space in the curriculum and in some has the dominant position, even where it has no statutory official status in the country, e.g. Bhutan and Maldives. In the competition for space, local languages have tended to be pushed aside and the complex multilingual realities of the region are not reflected in educational programs

\section{Case Studies}

\section{Case Study \#1 East Asia: Mainland China and Hong Kong SAR}

Mainland China provides a typical example of where the government has promoted the national language, Putonghua Mandarin, and English as the two main languages of education. The National Language Law of 2000 enshrines Putonghua as the national language and, at the same time, proscribes the use of other Chinese languages from the other dialect families (Yue, or Cantonese, Min or Hokien, Wu or Shanghainese, Hakka, Gan, Xiang) as languages of education. This means, for example, that, theoretically in any event, Cantonese cannot be used as a language of education in Mainland China. The demotion of languages such as Cantonese in this way has proved controversial.

The language that is the second language of education in China is English. This is introduced from grade 3 in primary schools nationwide. Such is the demand for English, however, especially in urban areas, that many English medium kindergartens have sprung up and many primary schools actually start teaching English from the start of schooling. The importance attached to English can be seen in the weighting it is currently given in the secondary school leaving exam, the gaokao, as it is one of only three core subjects, the others being maths and Chinese itself. Concern has been expressed about English being given equal weight to Chinese in the school system, but, to date, this has not resulted in any change. The number of English users in China has been estimated at 276 million (Bolton and Bacon-Shone 2020) and this gives some idea of how widespread the use of English is becoming in China. It is also increasingly used as a medium of instruction in higher education, a sector not covered by the Language Law.

While proscribing the use of Chinese languages other than Putonghua as languages of education, the Language Law does give ethnic minorities the right to develop and use their own languages. Officially there are 55 minority ethnic groups in China speaking 130 or so languages and comprising about $8 \%$ of the population or 100 million people. Feng and Adamson (2015) 
conducted a survey into how successfully trilingual education has been implemented in minority areas where the mother tongue was being taught alongside Putonghua and English. They identified four different models of trilingual education namely:

(i) the accretive model where the first language acts as the MoI for the first three years of primary and is then replaced by Putonghua while the first language is taught as a subject. English is taught as a subject from the first year.

(ii) the balanced model where the school has an equal number of Han and minority students and the school runs two streams, one using the minority language as the MoI, the other using Putonghua

(iii) the transitional model where Putonghua and English are given more priority than the minority language

(iv) the depreciative model where bilingualism in Putonghua and English is promoted at the expense of the minority language

However, Feng and Adamson point out that many schools in minority areas do not teach the minority language at all. They teach Putonghua and English. This is supported by Ding's research among the Primi (Pumi) ethnic group in Tibet who were being taught monolingually in Putonghua and that this 'coupled with extensive use of Mandarin in broadcast media is undoubtedly responsible for the language attrition reported by these younger speakers of Primi' (2015:25).

In short, except where the third language is seen to have some economic value, such as with Mongolian and Korean, trilingual education is not currently successful at maintaining minority languages in Mainland China, with only six (Uyghur, Kazak, Tibetan, Korean, Mongolian, and Yi) being considered safe (Feng and Adamson 2019). In Hong Kong, however, the emphasis is on trilingual education with the post 1997 Handover government keen to ensure its citizens become biliterate in Chinese and English and trilingual in Cantonese Mandarin and English.

Before the Handover in 1997, government primary schools used Cantonese as the medium of instruction and there was a laissez faire attitude in secondary schools, who were free to choose the MoI. As the government-funded universities are, with the exception of the Chinese University of Hong Kong, English medium, parents wanted their children to develop proficiency in English and most secondary schools therefore badged themselves as English medium. This was often EMI more in name than fact, however, and many schools adapted what was termed a technique of 'textual translation' where the teacher would translate the English textbook into Cantonese for the students who would then dutifully make notes in Cantonese (Luke and Richard 1982). The post-handover government clamped down on this and only allowed those schools which met certain strict criteria, which included having teachers and students with sufficiently high proficiency in English, to be EMI schools. The remainder were classified as Chinese medium of instruction (CMI) schools. The result was that only $25 \%$ of secondary schools were classified as EMI. This led to an almost immediate and then constant pressure from parents to allow CMI schools to teach subjects in English, as they felt this would help their children enter the universities. Eventually, after more than a decade of such pressure, the government relented and agreed to 'fine-tune' the medium of instruction policy (Kan et al.2011). This fine-tuning allowed CMI schools, but again only those that met certain criteria, to teach some subjects in English. This has led to more subjects in CMI schools being taught in English and fewer in Cantonese.

A reduction in the use of Cantonese as a medium of instruction has also been seen in primary schools. Since the Handover, the government has promoted the national language, Putonghua, 
as a school subject. In recent years, several schools have replaced Cantonese with Putonghua to teach Chinese itself. This requires a little explanation. Cantonese and Putonghua are mutually unintelligible but, to a very large extent, share a common written form, a shared set of characters (although there are some characters that are unique to Cantonese). The written forms of these characters are pronounced quite differently in Cantonese and Putonghua. As Putonghua Mandarin is the national language, the pronunciation of the characters in Putonghua is seen as standard; and it is argued by some scholars that using Putonghua to teach Chinese helps learners because the characters and the sounds match. Other scholars argue, however, that using the child's first language is more beneficial, and for an overwhelming majority of children in Hong Kong that is Cantonese. Recent research into the implementation of trilingual education in Hong Kong primary schools (Wang and Kirkpatrick 2013, 2019) show that different schools have adopted different methods dependent on their contexts and the linguistic backgrounds of their students. While the great majority of students are first language speakers of Cantonese, a number of schools near the border have Putonghua speaking students from the Mainland in their classes. This, along with recent immigration from the Mainland, means there is an increasing number of first language speakers of Putonghua in these schools. There is also a small, but not insignificant, number of non-Chinese students, especially from South Asia, the Philippines and Indonesia. Wang and Kirkpatrick (2019) therefore conclude that 'a schoolbased bottom up approach to develop a policy for trilingual education' is the most likely avenue to success (2019: 183). But there is, of course, a hugely critical political dimension to this. While Poon, in a recent survey of language policy in Hong (2019) predicts that the Hong Kong SAR will continue to promote the biliterate/trilingual policy, while favouring Putonghua and enforcing Putonghua as a medium of instruction for Chinese, recent political developments in Hong Kong may strengthen Cantonese as a language of local identity. People, above all parents, may then wish to see its position as a language of education in primary schools reinforced, especially as a medium of instruction for teaching Chinese.

\section{Case Study\#2 Southeast Asia: The Philippines}

The Philippines has had a complex colonial history, having been a colony of Spain from 1565 until 1898. Indeed the country is named after King Philip 2 of Spain. America became the new colonial master in 1898 when Philippines was ceded to America after America's defeat of Spain in the Spanish-American war. It became independent in 1946. The new colonial masters decided to make English the medium of instruction, a decision supported by some of those who had opposed the Spanish occupation. It was also supported by the colonisers as they thought English would help the locals 'imbibe and internalise democratic principles (Gonzales 1996:27). The adoption of English as an MoI appeared to have been successful as census figures of 1918 note that more than $50 \%$ of Filipinos ten years and over reported being able to speak the language.

As noted earlier, the Philippines is richly diverse linguistically with more than 170 languages spoken. In 1939, indigenous languages were allowed to be used in schools as 'auxiliary languages of instruction' alongside English (Gonzales 1996:27). In 1941, Tagalog, the language spoken around the capital, Manila, was adopted as the national language. This was a controversial decision as speakers of other languages felt they had been overlooked. In order to counter this criticism, the National Language Institute (Komyson sa Wakang Filipino) was tasked with creating a national language using Tagalog as the base, but including aspects of other Filipino languages. The resulting language Philipino, subsequently renamed Filipino, was really little more than Tagalog with ethnic additions (Kirkpatrick 2010:37). Today, however, most Filipinos seem to have accepted Filipino as their national language (Tupas 2007). 
Since independence and until relatively recently, Filipino and English have been the two main media of instruction. The Bilingual Education Policy (BEP) was implemented in 1974 and saw maths, science and English taught through English and all other subjects taught in Filipino. Despite many attempts by proponents of mother tongue education over many years to overturn the BEP and allow other languages as media of instruction, the policy remained in place until 2009 when the government legislated for a policy of mother tongue-based multilingual education (MTBMLE) avowing the importance of using the learner's mother tongue. 12 languages (later increased to 19) were gazetted to be used as media of instruction for the first three years of primary school. Added impetus to the move to MTB-MLE was provided in 2013 when the then President, Benigno Aquino, signed the Enhanced Basic Education Act (Republic of the Philippines 2013). Section 4 of the Act reads:

For kindergarten and the first three (3) years of elementary education, instruction, teaching materials and assessment shall be in the regional or native language of the learners. The Department of Education shall formulate a mother language transition program from Grade

4 to Grade 6 so that Filipino and English shall be gradually introduced as languages of instruction until such time when these two (2) languages can become the primary languages of instruction at the secondary level

This move to MTB-MLE has been criticised by some proponents of MTB-MLE for not going far enough, as they had called for mother tongue education throughout primary school. There have also been questions as to why the nineteen languages were chosen and whether more will be added, remembering that the Philippines is home to more than 170 languages. However, in a recent review of the policy, Young and Igcalinos (2019: 180) note encouraging results 'especially in areas where diverse cultures converge and collide over competing narratives', and that, in Mindanao in the Southern Philippines, the scene of much communal violence, MTB-MLE 'is slowly being embraced by parents and children themselves as this serves as a feeder to promoting a culture of peace and toleration'(2019:180). Young and Igcalinos also point out, however, that proponents of English mother tongue education remain powerful, citing the importance of high levels of English for the Philippines for its economically vital Business Processing Outsourcing (BPO) and Call Centre industries. It seems likely that MTB-MLE will take some time to bed in, and that English and Filipino will remain the major languages of education in the majority of primary schools. Yet, the Philippines is atypical in attempting to introduce at least some indigenous languages as languages of education.

\section{Case study\#3 Central Asia: Uzbekistan}

Uzbekistan is officially a monolingual state with Uzbek as the sole official language. However, it is also highly ethnically diverse with substantial minorities speaking Russian, Tajik, Kazakh, Kyrgyz and Tartar and it includes within its border the semi-autonomous Karakalpakstan republic. The education policy of Uzbekistan has a multilingual focus and recognises a free choice of MoI for schools. Initially the choice of MoI was recognised as a right in the 1992 education law, but this was later withdrawn in the 1997 law, although the actual practice does not seem to have changed. The education system has been largely decentralised and this means that many decisions are delegated to schools. The policy has specifically recognised Russian, Kazakh, Kyrgyz, Tajik and Turkmen but also requires that Uzbek be available as an MoI at all levels of education and that all schools teach Uzbek and Russian, In Karakalpakstan, all instruction is officially in Uzbek and Karakalpak (Bydanova \& Rozmetov, 2014; Liddicoat, 2019). Uzbek is the most widely used MoI in the republic, with Russian in second place 
especially in urban areas where it attracts not only members of the Russian ethnic group but also students from other groups (Khruslov, 2006).

Although Uzbek is the most widely used MoI, the implementation of Uzbek-medium education faces considerable problems because of a lack of sufficient numbers of qualified Uzbekspeaking teachers and of materials in Uzbek. The lack of materials has been compounded by a reluctance to use Soviet-era materials and by the change from Cyrillic to Latin script, which means older materials are not usable.

All schools teach Russian, but the amount of time devoted to Russian varies from school to school, as this is a matter on which decision-making has been delegated. This means that levels of acquisition can vary greatly across the country. Schools are also required to teach additional languages, and again the language chosen is left to the school. Even though this is a local choice, the usual language taught in Uzbekistan is English, with limited teaching of French, German and Hebrew (Hasanova, 2016). The 2012-13 curriculum revision effectively normalised this situation as it specifies that the foreign language taught should normally be English (Liddicoat, 2019). In many cases, schools have decreased the time allocations for Russian in order to fit English into their programs and there is thus competition between Russian and English for curriculum space (Landau \& Kellner-Heinkele, 2001). At tertiary level Russian is also a required subject. Students are also required to study a foreign language, which can be chosen from English, French, German or Spanish, although English is again the default offering (Hasanova, 2016).

Uzbekistan arguably has the most multilingual educational policy in Central Asia and allows many of the larger ethnic languages to be used as MoIs. However, like other republics, the titular language predominates in school and is required learning for all students. It is also typical in that Russian is a required subject and English is the main other language learnt in schools and universities. This effectively means that students in non-Uzbek-medium schools normally study four languages: the MoI, Uzbek, Russian and English, while in Uzbek-medium schools students study only three. The number of languages taught in schools inevitably means that there is competition for space and this competition is largely played out between English and Russian, with Russian increasingly seeming to give way to English.

\section{Case study\#4 South Asia: Bangladesh}

When Bangladesh separated from Pakistan in 1971, language issues played a major part. On achieving independence in 1947, Pakistan had enshrined Urdu as the language of the new nation and as symbol of national identity. This symbol, however, had little relevance for East Pakistan, where Bangla took on a symbolic role of language identity and, on its independence from Pakistan, became the official language of Bangladesh (Hamid \& Rahman, 2019). Although the majority of people in Bangladesh speak Bangla, the country has a number of minority groups speaking other languages with an estimated 36 indigenous and non-indigenous minority groups that have been largely ignored in Bangladesh's language policy (Tania Rahman, 2010).

Bangla became the normal MoI, with the former colonial language English taught as a subject in the school curriculum. Concerns over falling levels of English language ability since independence led to the strengthening of the place of English in the curriculum and in 1991, English was introduced as a compulsory subject from the beginning of schooling. The actual configuration of languages in Bangladeshi schools, however, varies according to the type of 
school. Hamid and Erling (2016) identify three distinct streams in Bangladeshi education, each of which has its own characteristic language policy. Most students are engaged in schools offering a general or secular education following the national curriculum and with Bangla as the language of instruction and English taught as a compulsory subject from Grade 1. A much smaller proportion of students attend madrasa schools which provide Islamic education and secular subjects. In these schools, Bangla is the MoI with Arabic and English being taught as compulsory subjects. The smallest proportion of students attend English- medium private schools.

Recently, there has been a shift in the language policy in public schools to open more space for English and qualified schools can now operate entirely in English or offer an English version alongside the Bangla curriculum and these schools are able to introduce more expensive fee structures (Hamid \& Rahman, 2019). Hamid and Rahman argue, that while this change may be seen as allowing parents more choice in education, at least for those with the financial resources to pay for it, they also represent an intrusion of private education services into public education and create a divide between those who can afford particular models of education and those who cannot. As discourses around English increasingly construct the language as important for modernisation, internationalisation and social mobility, differential access to programs constructs a form of inequality within the education system and within public education itself.

In addition, NGOs also play a considerable role in education in the country running programs for marginalized communities or ethnic minorities. Bangladesh is unusual in having a very high level of NGO presence in education and NGOs provide an important supplement to state level educational provision to meet education needs of diverse communities, especially in rural areas. Hamid and Rahman (2019) argue that NGOs have become so prevalent in education for disadvantaged groups that they call into question whether the Bangladesh government is still in control of education for such groups. This would appear to be especially the case for mother tongue education, which has been the preserve of NGOs as the languages have largely been ignored by the government in all aspects of educational policy.

As the educational sector appears to be increasingly caught between the privatisation of education, including differential fees in public schools and NGO control of educational programs, Hamid and Rahman (2019) argue that Bangladesh may be facing a situation in which the government's control of and ability to direct the educational agenda may be weakening and passing to the hands of others. As privatised education and NGOs tend to focus on teaching and learning of English or minority languages, this may mean that the agenda for official language education is being weakened as the government is making less investment in the national language and its development.

\section{Common themes in language education policy in Asia}

Across the Asian region, there are a number of common themes that emerge in language education policy. These common themes are seen in the role of official languages in education, the place of English and the place of indigenous mother tongues.

Most of the countries of the Asian region have adopted language policies that support a single official language. However, some countries have adopted multilingual policies either with multiple local languages (e.g. India, Singapore, Sri Lanka, Afghanistan) or with a former colonial language being retained alongside a local language (e.g. English in Singapore, India, Philippines, Hong Kong; Portuguese in Timor Leste; Russian in Kyrgyzstan and Kyrgyzstan). Many of the countries of the region have given a great deal of attention to literacy development in the official language, with many raising literacy levels very substantially since the mid-20th 
century. Literacy in the official language was closely tied with policies to spread the official language widely in the nation, especially where the nation was multilingual and substantial parts of the population did not speak it. In officially monolingual nations, the official language has typically been the sole language of schooling and other languages at best have been given only marginal roles. In officially multilingual societies, the question of $\mathrm{MoI}$ has been more complex and often reveals an inequality between the languages. In Singapore, the former colonial language, English, has been adopted as the normal medium of instruction, the other official languages as subjects in the curriculum (Jain \& Wee, 2019). In the Central Asian republics of Kazakhstan and Kyrgyzstan, the emphasis is placed on the local languages Kazakh and Kyrgyz and Russian is much less frequently used as the main medium of instruction and access to Russian schools may be limited (Liddicoat, 2019; Regan, 2019). In Macau, Portuguese has a very marginal role in education compared to Chinese and even to English, which has no official status (Moody, 2019). In Hong Kong, MoI has become controversial, as education in English-medium schools is seen as better quality and more desirable than education in Chinese-medium schools and there is pressure from parents to move away from Chinese as the MoI (Poon, 2019). In Afghanistan and Sri Lanka, policy seems to treat the languages more equally and requires the learning of both languages, one as the MoI and one as a subject (Liyanage, 2019; Spooner \& Nawad, 2019).

In most of the countries under review English is promoted, along with the national language as one of the two major languages of education. Those countries which were colonised by English-speaking nations have retained English, often in institutional roles and as a semiofficial or additional official language. In many countries or polities with a colonial connection with English, English has been adopted as an MoI, often replacing local languages even where they have official status, as in Singapore (Jain \& Wee, 2019), or has become a dominant MoI as the result of its perceived status as in Bangladesh (Hamid \& Rahman, 2019), Bhutan (Dukpa, 2019) or Hong Kong (Poon, 2019). In some cases, the continued use of the colonial language was seen as temporary while a local language was developed to meet official needs although in reality it as often been difficult to dislodge English. In India, for example, English was recognised in India's 1950 constitution with a time limit of 15 years on its use before it would be placed by Hindi (Graddol 2010: 52). In education, the current 'three language formula' calls for Hindi-speaking children also to learn English and one other Indian language, and for nonHindi speaking children to learn their first language, Hindi and English. In fact, most Hindi speakers learn only English as well as Hindi, and most non-Hindi speakers prefer to learn English ahead of Hindi. However, as Mohanty points out, English has become 'the most common second language in all the states' (2019:333).

Even in countries where English does not have a colonial legacy and where English has no official status, it has tended to become the main, and in some cases sole foreign language taught in government educational systems. This is the common pattern throughout the region for all countries in which English is not a usual MoI, with the exception of the Central Asian republics where Russian still holds a dominant position, although this position seems to be eroding in favour of English. One feature of the teaching of English as a foreign language has been a movement to an early start in language learning, often beginning in early primary school. Currently, in most of the Asian region, foreign language education is synonymous with the teaching and learning of English, whether this is officially recognised in policy documents or not; other foreign languages have, at best, a minimal role. The most notable exception is in Central Asia, where Russian has held at least some of its former position but is now being increasingly challenged by English (Liddicoat, 2019; Regan, 2019). Even though the position of other languages may be precarious, other languages are nonetheless present and foreign 
languages may be taught in schools and, more widely, in universities. Yet much learning of foreign languages is undertaken in elective $a b$ initio tertiary level programmes.

Apart from being a legacy of a colonial past, the primary motivator for the growth of English in the region has been the increasing globalised role of English and an ideological positioning of English as the language of modernisation and economic opportunity, supported by the neoliberal agenda of education for economic utility (Piller \& Cho, 2013). The predominance of English in Asia is not only a feature of individual polities' policies, but is also supported by supra-regional bodies, most significantly ASEAN (the Association of Southeast Asian Nations). As noted earlier, the ASEAN Charter of 2009 made English the only official working language of the group (Kirkpatrick 2010). The model of the respective national language plus English as the two major languages of education is typical across the region.

Indigenous languages, other than official languages, have at best a marginal role in education in most of the countries of the region. Ethnic minorities are expected to use the national language as the medium of instruction and as a medium of communication while at school. Students for whom the national language is not used in the home thereby experience great educational disadvantage. Indigenous languages other than the national language are typically only taught outside mainstream school. In the context of Mainland Southeast Asia, Bradley (2019:26) concludes:

In all countries of mainland Southeast Asia, indigenous ethnic minority languages are largely excluded from the government education system as a consequence of policies in support of the national language. This means that indigenous ethnic minorities are in most cases greatly disadvantaged when they start school in the national language. At present, the main domain for learning literacy in indigenous minority languages is through religious institutions.

This situation is mirrored throughout the region, although non-governmental organisations (NGOs) also offer education in indigenous languages in certain countries. For example, and as noted in the Bangladesh case study below, NGOs are significant providers of education in Bangladesh. The NGO, Building Resources Across Communities (BRAC), is the largest NGO in the world and is heavily involved in providing education in the country. In addition to offering mainstream education across some 40,000 pre-primary and primary schools, it also runs 1635 schools in the South East of the country offering multilingual education in the child's first language, the national language, Bangla and English (Hamid \& Rahman 2019)

In India, as in many of the other contexts discussed here, the rhetoric of language policy in education remains fractured between a political desire to promote the mother tongues and indigenous identities of the masses in a multilingual society and, at the same time, to cater to the growing popular craze for English. In this 'battle' between English and indigenous languages, English emerges on top, as the hegemonic role of English in Indian education has forced a monolingual orientation to education in a country where multilingualism is the social reality (Mohanty 2019). There are some exceptional cases of mother tongue-based multilingual education. The regional government of Odisha is offering MTB-MLE, for example. In Cambodia, a Multilingual Education National Action Plan (MENAP) has been operating since 2015. As of early 2016, more than 5500 children had studied in or were attending formal schools providing multilingual education, and 150 people have been trained as teachers in multilingual education (Kosonen 2019). The overall picture with regard mother tongue-based multilingual education and the teaching and learning of indigenous languages is bleak, however. 
Benson (2020) estimates that $40 \%$, or 2.3 billion, of the world's people still lack access to instruction in a language they speak or understand.

\section{Conclusion}

This overarching review of language education policy in Asia points allows a number of trends to be identified (and see Kirkpatrick \& Liddicoat 2019). While there are exceptions as in the Philippines where 19 local languages are being promoted as languages of education in the early years of primary, generally speaking these countries and polities are promoting their respective national language as the major language of education. In some countries, however, NGOs are promoting education in indigenous minority languages, but often with little support from national governments and thus risks for their long term sustainability and few prospects of expanding provision of such programs. The focus on the national languages is not much different from education policies in most parts of the world, but in Asia it may have an added importance as many of these states are relatively newly independent and see the development and promotion of a national language as integral to national unity. At the same time, many may see the promotion of local languages other than the national language as inimical to the ideology of a unified nation state, fearing the learning of local languages may encourage some form of 'splittism'. At the same time, many regard proficiency in English as crucial for being able to participate in and benefit from globalisation and are thus promoting English as the second language of education and introducing it earlier and earlier into the primary school curriculum. We have noted how a shortage of suitably qualified teachers and appropriate materials means that this promotion of English has met with extremely limited success in many cases. Making English the second language of education may also undermine the role of local and home languages in education and so reinforce situations where children are being required to study in languages they do not understand. We have also argued that a language education policy that promotes the national language and English further privileges the already privileged middle classes and widens the gap between the 'haves' and the 'have nots'. This is particularly noticeable in the urban-rural divide. To conclude we list the five major trends we have been able to discern in this overview of language education policy in Asia. They are:

(i) the promotion of the respective national language as a symbol of national identity and unity;

(ii) the promotion of English as the second language of education;

(iii) as a result of (ii) an increasing division between the 'have' and 'have nots' as government schools often face shortages of qualified English teachers and lack access to suitable materials;

(iv) limited support for indigenous languages in education, and often they are present in policy documents but not in reality;

(v) as a result of (ii) and (iv) many children are having to learn in languages they do not understand.

One consequence of these trends is that the linguistic diversity of Asia is marginalised in educational contexts in favour of a bilingual educational model based on the national language and English and thus it would seem that education not supportive of the maintenance of linguistic diversity in Asia.

\section{References}


ASEAN (2013) Keynote address by H. E. Le Luong Minh, Secretary-General of ASEAN at the British Council Conference on 'Educating the next generation of workforce: ASEAN perspectives on innovation, integration and English'. Bangkok, June 242013

Benson, C. (2019). Li-based multlingual eduation in the Asia and Pacific region and beyond. Where are we and where do we need to go? In A. Kirkpatrick \& A. J. Liddicoat (Eds.), The Routledge international handbook of language education policy in Asia (pp. 2941). Abingdon and New York: Routledge

Bolton, K \& Bacon-Shone, J. (2020, in press). The statistics of English across Asia. In K. Bolton, W. Botha \& A. Kirkpatrick (Eds.), The handbook of Asian Englishes. Hoboken, NJ: Wiley Blackwell

Boyle, Helen N. (2006). Memorization and learning in Islamic schools. Comparative Education Review, 50(3), 478-495. doi:10.1086/504819

Bradley, D. (2019). Minority language learning in mainland Southeast Asia. In A. Kirkpatrick \& A. J. Liddicoat (Eds.), The Routledge international handbook of language education policy in Asia (pp. 14-28). Abingdon and New York: Routledge

Bydanova, L., \& Rozmetov, D. (2014). Évolutions récentes du système éducatif de l'Ouzbékistan. Revue internationale d'éducation de Sèvres, 65, 1-7. doi:10.4000/ries.3671

Chandralal, D. (2010). Sinhala. Amsterdam, Philadelphia: John Benjamins.

Ding, P.S. (2015). Value of Primi: knowledge of traditional culture in a threatened language. In Indigenous languages: Value to the community. Bath: Foundation for Endangered Languages, 21-26.

Dovchin, S. (2017). Translocal English in the linguascape of Mongolian popular music. World Englishes 36(1), 2-19.

Draper, J. (2019) Language education policy in Thailand. In A. Kirkpatrick \& A. J. Liddicoat (Eds.), The Routledge international handbook of language education policy in Asia (pp. 229-242). New York: Routledge.

Dukpa, L. (2019). Language policy in Bhutan. In A. Kirkpatrick \& A. J. Liddicoat (Eds.), The Routledge international handbook of language education policy in Asia (pp. 355-363). New York: Routledge.

Feng, A and Adamson, R.A. (2019). Language policies in education in the People's Republic of China. In A. Kirkpatrick \& A. J. Liddicoat (Eds.), Routledge international handbook of language education policy in Asia (pp. 45-59). New York: Routledge.

Feng, A \& Adamson, R.A. (Eds.) (2015). Trilingualism in education in China: models and challenges. Dordrecht: Springer.

Gnanadesikan, A. E. (2017 ). Dhivehi: The language of the Maldives. Berlin: de Gruyter Mouton.

Gonzalez, A.B. (1996). The history of English in the Philippines. In M. L. Bautista (Ed.). English is an Asian language: the Philippine context.(pp 25-40). Sydney: The Macquarie Library.

Graddol, D. (2010). English next: India. London: The British Council

Hamid, M. O., \& Erling, E. J. (2016). English-in-education policy and planning in Bangladesh: A critical examination. In R. Kirkpatrick (Ed.), English language education policy in Asia (pp. 25-48). Cham: Springer International Publishing.

Hamid, M. O., \& Rahman, A. (2019). Language education policy in Bangladesh: A neoliberal turn? In A. Kirkpatrick \& A. J. Liddicoat (Eds.), The Routledge international handbook of language education policy in Asia (pp. 382-390). Abingdon and New York: Routledge.

Hasanova, D. (2016). English education in Uzbekistan. In E. S. Ahn \& J. Smagulova (Eds.), Language change in Central Asia (pp. 245-265). Boston, Berlin: de Gruyter Mouton. 
Honna, N \& Saruhashi, J. (2019).Langugae education policy in Japan. In A. Kirkpatrick \& A. J. Liddicoat (Eds.), Routledge international handbook of language education policy in Asia (pp. 97-110). New York: Routledge.

Jain, R., \& Wee, L. (2019). Language education policy: Singapore. In A. Kirkpatrick \& A. J. Liddicoat (Eds.), Routledge international handbook of language education policy in Asia (pp. 272-285). New York: Routledge.

Jennar, R. (1997). La francophonie en Asie : Cambodge, Laos et Viêtnam. Politique et Sociétés, 16(1), 119-127. doi:10.7202/040052ar

Jeon, J (2019). Language education policies in Siuth Korea. In A. Kirkpatrick \& A. J. Liddicoat (Eds.), Routledge international handbook of language education policy in Asia (pp. 111-123). New York: Routledge.

Kalainathan, R. (2000). Linguistic heritage of Sri Lankan Tamil. In O. N. Koul \& L. Devaki (Eds.), Linguistic heritage of India and Asia (pp. 300-304). Mysore: Central Institute of Indian Languages.

Kan, V., K. C. Lai, A. Kirkpatrick, \& A. Law. (2011). Fine-tuning Hong Kong's medium of instruction policy. Hong Kong: Strategic Planning Office \& Research Centre into Language Education and Acquisition in Multilingual Societies, The Hong Kong Institute of Education.

Khruslov, G. (2006). Функционирование русского языка в странах СНГ [Functioning of the Russian language in CIS countries]. Russian Language Journal, 56(5), 131-166.

Kirkpatrick, A (2016). The future of English in Asia. In M. O'Sullivan, D. Hubbard \& C Lee (Eds.) The future of English in Asia (pp. 3-19). London and New York: Routledge

Kirkpatrick, A. (2010). English as a lingua franca in ASEAN: A multilingual model. Hong Kong: Hong Kong University Press

Kirkpatrick, A \& Liddicoat, A.J. (2019). Overview. In A. Kirkpatrick \& A. J. Liddicoat (Eds.), The Routledge international handbook of language education policy in Asia (pp..3-13. ). New York: Routledge.

Kirkpatrick, A.\& Liddicoat, A.J. (2017). Language policy in Asia. Language Teaching 50(2), 155-188.

Kohler, M. (2019) Language education policy in Indonesia: a struggly for unity in diversity. In A. Kirkpatrick \& A. J. Liddicoat (Eds.), The Routledge international handbook of language education policy in Asia (pp. 286-297). New York: Routledge.

Kosonen, K. (2019). Language education policy in Cambodia. In A. Kirkpatrick \& A. J. Liddicoat (Eds.), Routledge international handbook of language education policy in Asia (pp. 216-228). New York: Routledge.

Landau, J. M. (2010). Alphabet reform in the six independent ex-Soviet Muslim republics. Journal of the Royal Asiatic Society 20(01), 25-32. doi:10.1017/S1356186309990289

Landau, J. M., \& Kellner-Heinkele, B. (2001). Politics of language in the ex-Soviet Muslim states: Azerbaijan, Uzbekistan, Kazakhstan, Kyrgyzstan, Turkmenistan and Tajikistan. Ann Arbor, MI: University of Michigan Press.

Liddicoat, A. J. (2019). Language-in-education policy in the Central Asian republics of Kyrgyzstan, Tajikistan, Turkmenistan, and Uzbekistan. In A. Kirkpatrick \& A. J. Liddicoat (Eds.), The Routledge international handbook of language education policy in Asia (pp. 452-470). New York: Routledge.

Liyanage, I. (2019). Language education policy in Sri Lanka. In A. Kirkpatrick \& A. J. Liddicoat (Eds.), The Routledge international handbook of language education policy in Asia (pp. 399-413). Abingdon and New York: Routledge.

Luke, K. K., \& Richards, J. C. (1982). English in Hong Kong: Functions and status. English World-Wide, 3(1), 47-64. 
Marzluf, P \& Saruul-Erdene, M. (2019). In A. Kirkpatrick \& A. J. Liddicoat (Eds.), Routledge international handbook of language education policy in Asia (pp. 137-150). New York: Routledge.

Meyers, C. (2019). Lao language policy. In A. Kirkpatrick \& A. J. Liddicoat (Eds.), Routledge international handbook of language education policy in Asia (pp. 203-215). New York: Routledge.

Mohamed, N. (2019). From amonolingual to a multilingual nation: Analysing the language education policy in the Maldives. In A. Kirkpatrick \& A. J. Liddicoat (Eds.), The Routledge international handbook of language education policy in Asia (pp. 414-426). Abingdon and New York: Routledge.

Mohanty, A. K. (2019). Language policy in education in India. In A. Kirkpatrick \& A. J. Liddicoat (Eds.), The Routledge international handbook of language education policy in Asia (pp. 329-340). Abingdon and New York: Routledge.

Moody, A. (2019). Educational language policy in Macau: Finding balance between Chinese, English and Portuguese. In A. Kirkpatrick \& A. J. Liddicoat (Eds.), Routledge international handbook of language education policy in Asia (pp. 77-96). New York: Routledge.

Nault, D.M. (2012). English in India's national development. Hindi-Dravidian politics and the retention of a colonial language. Asian Englishes 15(1), 68-87.

Nguyen, X. N. C. M., \& Nguyen, V. H. (2019). Language education policy in Vietnam. In A. Kirkpatrick \& A. J. Liddicoat (Eds.), Routledge international handbook of language education policy in Asia (pp. 185-201). New York: Routledge.

Phyak, P., \& Ojha, L. P. (2019). Language education policy and inequalities of multilingualism in nepal: Ideologies, histories and updates. In A. Kirkpatrick \& A. J. Liddicoat (Eds.), The Routledge international handbook of language education policy in Asia (pp. 341354). Abingdon and New York: Routledge.

Piller, I \& Cho, J. (2013). Neoliberalism as language policy. Language in Society, 42(1), 2344.

Poon, A. Y. K. (2019). Language education policy in Hong Kong. In A. Kirkpatrick \& A. J. Liddicoat (Eds.), Routledge international handbook of language education policy in Asia (pp. 60-75). New York: Routledge.

Rahman, T. (2010). A multilingual language-in-education policy for indigenous minorities in Bangladesh: Challenges and possibilities. Current Issues in Language Planning, 11(4), 341-359.

Rahman, T. (2019). Mother tongue education policy in Pakistan. In A. Kirkpatrick \& A. J. Liddicoat (Eds.), The Routledge international handbook of language education policy in Asia (pp. 364-381). Abingdon and New York: Routledge.

Regan, T. (2019). Language planning and language policy in Kazakhstan. In A. Kirkpatrick \& A. J. Liddicoat (Eds.), The Routledge international handbook of language education policy in Asia (pp. 442-451). New York: Routledge.

Republic of the Philippines (2013) An act enhancing the Philippine basic education system by strengthening its curriculum and increasing the number of years for basic education, appropriating funds therefor and for other purposes. Retrieved from http://www.gov.ph/2013/05/15/republic-act-no-10533/.

Rubinger, R. (2007). Popular literacy in early modern Japan. Honolulu, HI: University of Hawai'i Press.

Song,J.(2019). Language education policy in North Korea. In A. Kirkpatrick \& A. J. Liddicoat (Eds.), Routledge international handbook of language education policy in Asia (pp. 124-136). New York: Routledge. 
Spooner, B., \& Nawad, S. (2019). Language education policy in Afghanistan. In A. Kirkpatrick \& A. J. Liddicoat (Eds.), The Routledge international handbook of language education policy in Asia (pp. 429-441). Abingdon and New York: Routledge.

Tupas, R. (2007). Go back to class: the medium of instruction debate in the Philippines. In L.H. Guan \& L. Suryadinata (Eds.). Language, nation and development.(pp: 39-50). Singapore: Institute of Southeast Asian Studies.

Wang L. \& Kirkpatrick, A. (2013). Trilingual education in Hong Kong primary schools: a case study. International Journal of Bilingual Education and Bilingualism, 1691), 100-116.

Wang,L. \& Kirkpatrick, A. (2019). Multilingual Education in Hong Kong Primary Schools.Dordrecht: Springer.

Wu, L \& Lau, K. (2019). Language education policy in Taiwan. In A. Kirkpatrick \& A. J. Liddicoat (Eds.), The Routledge international handbook of language education policy in Asia (pp. 151-162). Abingdon and New York: Routledge.

Young, C \& Igcalinos, T. (2019).Language-in-education policy development in the Philipppines. In A. Kirkpatrick \& A. J. Liddicoat (Eds.), The Routledge international handbook of language education policy in Asia (pp. 165-184). Abingdon and New York: Routledge. 